\title{
Blått og kaldt
}

\section{Samtidens hardkokte økonomi-}

logikk erå styre etter fordummende

måltall, undergrave faglighet og

fortrenge omtenksomt nærvær til

pasienter, barn og elever. Premiss-

leverand $\varnothing r$ er bedrifts $\varnothing$ konomien,

sannsynligvis den svakeste av alle

samfunnsvitenskapene.

Rusfaget er en hybrid av ulike vitenskaper med et omfattende kunnskapstilfang fra blant annet medisin, psykologi, sosiologi, filosofi og økonomi. Faget handler om folkehelse og forebygging, om veier inn i og ut av rusproblemer. Ikke noe enkelt fagfelt eller politikkområde favner denne helheten. Vi som arbeider i rusfeltet må lyse opp denne kompleksiteten, slik at den langsiktige forebyggingen ikke drukner i strakstiltak og rapporteringer.

Da må vi også blande oss i den politiske samtalen. Er det kanskje noe i tidens krav til effektivitet og måloppnåelse i utdanningssamfunnet, prestasjonssamfunnet og i jakten på det normale barnet som river mennesker løs fra konstruktive fellesskap? Med regjeringsskifte frykter jeg en forverring på rusfeltet. Nå står det riktignok i fellesavtalen som ble lagt frem 30. september at behandlingstilbudet skal styrkes, og det er bra, blant annet ved å kjøpe flere behandlingsplasser og etablere et mer sammenhengende behandlingsløp. Men hva med de andre politikkområdene?

Jeg frykter en skolepolitikk fremover der konkurransen skjerpes, mellom skoler og mellom elever. Med større vekt på «fritt skolevalg» er det grunn til å frykte en tilspisset skolehverdag der kanskje direktørens datter velger en annen skole enn sønnen til den trygdede. Jeg frykter en barnehagehverdag der effektivisering og hensynet til lønnsomhet i enda større grad går foran hensynet til barnas beste. Jeg frykter et arbeidsliv med flere usikre og kortsiktige kontrakter. Jeg frykter at forskjeller i levekår vil øke, at de velstående løper ytterligere fra de ubemidlede. Jeg frykter at stadig flere velferdsgoder havner på torget for kjøp og salg. Du blir ikke nødvendigvis rusavhengig, kriminell eller outsider av en trøblete skolegang eller manglende lønnsarbeid. Men du er noe nærmere hverdager der du møter andre som har lite å tape.

Jeg er skuffet over at den avtroppende regjeringen fikk gjort så lite med å avskaffe fattigdom og at antallet milliardærer i Norge doblet seg i løpet av de åtte årene de regjerte. Jeg er forbannet for at de medvirket til at sykehusene ble til foretak og at de tviholder på New Public Management, denne markedsstyringen der kvantitet settes foran menneskelig livskvalitet. Jeg gleder meg over Helsetjenesteaksjonen som kjemper for faget og omsorgen for pasientene og for å skrote New Public Management.

Den påtroppende regjeringen har kullsviertro på vekst, konkurranse og ytterligere effektivisering og samordning av tjenester. Konkurransen skal visstnok vekke slumrende energier i folk og virksomheter, med stadig forbedring som resultat. Ja, muligens i idretten, men hva med obligatorisk skole, der de unge ikke kan beskytte seg mot konkurransenederlag? Professor i sosialmedisin Steinar Westin sa det så treffende i et portrettintervju i Klassekampen (12.8. 2006):
«Jeg tror ikke det er samordningen mellom etater som er hovedproblemet. Vi leger ser på nært hold hvordan de markedsøkonomiske grepene, omstillingene og rasjonaliseringene i arbeidslivet spinner folk ut i velferdsnettet som en gigantisk sentrifuge. Det er på tide å tenke lengre enn å flikke på problemet, ved å få tilbake en samfunnsøkonomisk tankegang i stedet for den rådende markedsliberalisme».

Nå får vi mer markedsliberalisme. Skattepolitikken til den nye regjeringen vil føre til enda større forskjeller mellom folk. Bortfall av arveavgiften vil bety at de økonomiske skillene i sterkere grad vil gå i arv mellom generasjoner. Det er grundig dokumentert, ikke minst fra samfunnsmedisinsk hold, at i land med små forskjeller er befolkningens helse bedre, narkotikaproblemene mindre, kriminaliteten lavere og tilliten mellom folk høyere (Wilkinson R, Pickett K. Ulikhetens pris. Oslo: Res Publica, 2011).

En kald økonomilogikk kan fort svekke sammenhengskraften i det norske samfunnet. Det sosiale limet som holder fellesskapet samlet, kan tørke ut. Det står mye på spill. Per i dag er norsk skole grunnleggende human og med mye inkluderende omsorg. Fellesskolen er selve stolpen i velferdsstaten. Jeg tror vi får se mer til den sosiale tyngdeloven, der barn med vanskelig utgangspunkt ikke når opp i konkurransesamfunnet. Jeg frykter flere spisse albuer og flere tapere. Alt dette som uønskede resultater av en valgt politikk.

Og jeg håper jeg tar feil.

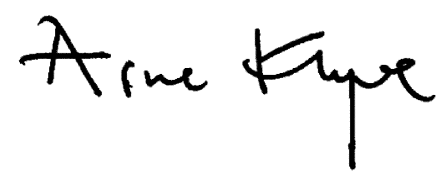

